\title{
VESTIR LAS PALABRAS: GRABADOS XILOGRÁFICOS EN LA FICCIÓN SENTIMENTAL
}

\author{
Carmen Parrilla García \\ Universidad de A Coruña \\ calala@udc.es
}

En el género de la ficción amorosa de los siglos XV-XVI, una segunda serie de obras nace y se desarrolla en Castilla y en la Corona de Aragón al tiempo que la industria de la imprenta se afianza y prospera en la Península por la iniciativa de los maestros centroeuropeos. Sin embargo, una obra afín a este grupo, el Triunfo de Amor de Juan de Flores, tildada de 'novela' por el propio autor y de decisivo contrafactum por Gómez Redondo ${ }^{1}$, merecería haber gozado de las iniciativas impresoras de los últimos años del siglo xV, ya que en esta obra, aliada y coaligada al grupo sentimental, el afán descriptivo en movimiento, imaginería y efectos escénicos son cualidades que hubieran podido propiciar su salida a la imprenta acompañada de ilustraciones, antes de cerrarse la centuria de los incunables. Distinta suerte corrió otra obra de Flores que pronto se divulgó impresa: Grisel y Mirabella (¿1495?) atribuida a las prensas de Enrique Botel $^{2}$. Esta primicia no lleva en su interior grabado alguno. Un único ejemplar se encuentra en la BNE, I 2181, procedente de la biblioteca de Pascual de Gayangos y su título anuncia simplemente: Tractado compuesto por Johan de Flores a su amiga. Destaca esta obra por la reiteración en ella del debate secular entre hombres y mujeres -característica

\footnotetext{
${ }^{1}$ Fernando Gómez Redondo, Historia de la prosa de los Reyes Católicos: El umbral del Renacimiento, II, Madrid, Cátedra, Crítica y Estudios Literarios, 2012, pp. 1436-1448.

${ }^{2} \mathrm{El}$ sajón Henrique Botel es uno de los primeros impresores que se establecen en España. Como maestro de imprimir y especializado en la letra gótica se asocia en Barcelona en 1473 con dos discípulos: Planck y Von Holtz, hasta 1478. Debió de colaborar con Pablo Hurus aun estando en sociedad con Planck. Al dejar la compañía de los antiguos discípulos se establece en Lérida, tal vez a instancias de la Iglesia leridana y del propio Estudio general para quienes realizó varios trabajos. Miguel Ángel Pallarés Jiménez, La imprenta de los incunables de Zaragoza y el comercio internacional del libro a finales del siglo XV, Zaragoza, «Institución Fernando el Católico» (CSIC) - Excma. Diputación de Zaragoza, 2003, pp. 49-61.
} 
polémica en el subversivo Triunfo de Amor-, pero en este caso Flores escoge a un paladín de renombre; nada menos que al misógino poeta catalán Pere Torroella, autor de las Coplas de las calidades de las donas: «the casus belli of a veritable courtiers war» ${ }^{3}$, que circulaban transmitidas en varios cancioneros desde mediados del siglo xv. Así, Juan de Flores incluye en Grisel y Mirabella al propio Torroella para formar parte decisiva en su historia, con lo que el título de esta obra se popularizó como Historia de Grisel y Mirabella con la disputa de Torrellas y Braçayda. Aunque al público lector hubo de interesarle la trágica narración sobre el mutuo sentimiento profundo y generoso de los amantes, sin embargo tal vez caló con mayor fuerza el debate verbal entre los respectivos defensores de cada sexo, por lo que generalmente la ilustración de tal contienda entre Torroella y Braçayda sobresale en la portada de la mayoría de los impresos conservados ${ }^{4}$. Con todo, una excepción parece hallarse en la edición del salmantino Juan Varela de Salamanca, avecindado en Sevilla, al menos desde 1501 y que en 1514 publica la obra y proporciona el primer grabado de portada hasta ahora conocido ${ }^{5}$ (fig. 1).

En la portada, encuadrada en un marco decorado por ánforas y motivos vegetales se representa una estancia que puede interpretarse como aquel «lugar muy secreto» en el que el celoso rey guarda a su hija Mirabella. Muros y suelo de piedra; dos arcos ventanales. En escorzo, un caballero y una dama, de pie, parecen conversar. El hombre viste capuz o tabardo con capilla que permite ver parte de un sayo y se cubre con una carmeñola. La dama está envuelta en un manto que no permite ver con detalle el vestido; en la cabeza una sencilla cofia. Si representan a los amantes de la ficción de Flores, acaso se trate de elementos simbólicos de la historia lo que cada uno lleva en su mano izquierda: un bastón o vara - ¿de justicia?- el hombre, y una larga palma la mujer.

${ }^{3}$ Bárbara Matulka, «An Antifeminist Teatrise of Fifteenth Century Spain: Lucena's Repetición de amores», en The Romanic Review, 22:2 (1931), pp. 99-116, cita p. 99.

${ }^{4}$ Hay noticia de esta obra de Flores en 1511, según se recoge en la relación de bienes extraída del testamento del regidor de Santiago de Compostela, Francisco de Treviño, otorgado el 27 de septiembre de 1511 y conservado en el Tumbo F del archivo catedralicio, ff. 9v-21r. Entre una veintena de libros se hallan «Otro de Correllas y Bracaida, Otro de Celestina», lo que prueba la popularidad de estos decisivos intervinientes. Véase, Antonio López Ferreiro, Galicia en el último tercio del siglo XV, Santiago, Imprenta de la Gaceta, 1883, p. 462 y Mercedes Vázquez Bertomeu, La hacienda arzobispal compostelana: libros de recaudación (1481-1483 y 1486-1491), Madrid, CSIC, 2002.

${ }^{5}$ Para Norton, esta impresión de Grisel pertenece a la primera etapa en Sevilla de Juan Varela, quien había trabajado antes en Granada. La imprenta en España (1501-1520), [1966], ed. anotada por Julián Martín Abad, Madrid, Ollero \& Ramos, 1997, p. 45. Según Jaime Moll, procedía de Toledo, en donde debió de trabajar en el taller de Villaquirán, que anteriormente había pertenecido a Pedro Hagenbach. Jaime Moll, «Los talleres de imprenta en Toledo entre 1524 y 1535», en Trabajos de la reunión de la Asociación Española de Bibliografia (2003), Madrid, Asociación Española de Bibliografía, Biblioteca Nacional, 2004, pp. 133-141. Se casará con una hija del impresor Jacobo Cromberger, por lo que se unirán estos talleres. 
De la imprenta sevillana de Cromberger se conservan varias ediciones: $1524,1526,1529,1533$ que ofrecen idéntico grabado en la portada, aunque enmarcado por diferentes orlas; grabado que evidentemente sugiere el sustancial debate de la historia (fig. 2). En la imagen se hace referencia expresa al combate dialéctico de Torroella y Braçayda: una dama y un caballero departen animadamente, lo que se refleja en la postura del hombre, presentado frontalmente, los brazos abiertos en actitud declamatoria. La oponente, de perfil, extiende el brazo izquierdo hacia su dialogante, en actitud de intervenir. Detrás de ella otra dama, vuelto el rostro hacia la izquierda, parece dirigirse a alguien no presente en la escena, - ¿la compañía femenina de Braçayda?- sugiriéndose con ello el desgraciado final de Torroella a manos de las mujeres, según el relato de Flores. El adversario viste ropa corta con mangas muy anchas y se cubre la cabeza con una especie de abultado capirote de rollo. La vestidura amplia y lujosa, recamada en los bordes, contrasta con el calzado, ya que las calzas van introducidas en unos alcorques. La dama que se halla en primer témino porta amplio manto que deja ver una pequeña parte de la prenda interior. Apenas se aprecia el ajustado vestido de la otra dama. Ambas se cubren la cabeza con sendas crespinas de las que escapan algunos cabellos. En la composición de esta portada las imágenes parecen proceder de dos modelos xilográficos distintos. La figura de Torrroella es sobresaliente en la composición de la escena, por tamaño, por su posición frontal y la extensión de sus brazos separados del cuerpo pero, sobre todo por su expresividad. Con la cabeza levemente inclinada hacia Braçayda, en el rostro de Torroella

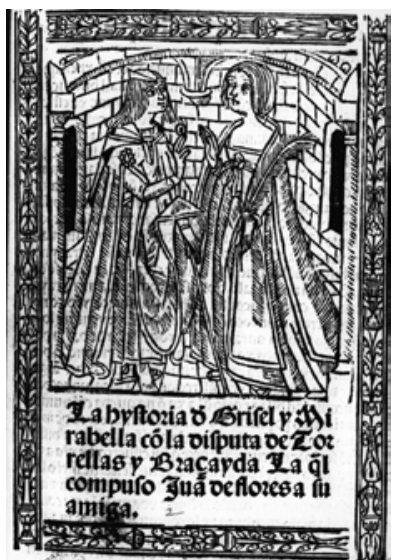

Fig. 1. Grisel y Mirabella, (Sevilla, Juan Varela de Salamanca, 1524) Bibl. de Catalunya, Espona, 80, 8.

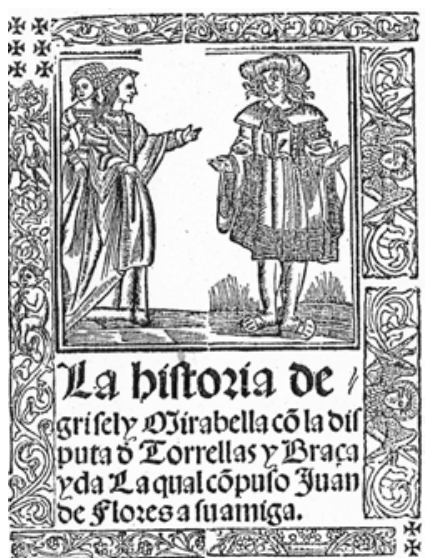

Fig. 2. Grisel y Mirabella (Sevilla, Juan Cromberger, 1529) BNE Cerv. Sedó 8630.

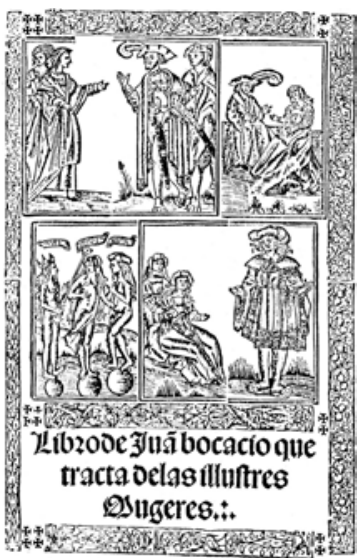

Fig. 3. Libro de las ilustres mujeres, (Sevilla, Jacobo Cromberger, 1528), Valencia, BH, BHR/1/ 097 (1). 
se logra un rictus que parece insinuar su victoria en el debate. Estas portadas de la imprenta de Cromberger rebasan su función decorativa e informativa, ya que remiten a la sección decisiva de la trama argumental de Grisel y Mirabella, manifestando así la función primordial y utilitaria de este específico grabado. En la misma imprenta de Cromberger sale en 1528 el Libro de Juan Bocacio que tracta de las illustres mugeres. En el frontispicio se presenta un grabado compuesto por tacos que emplean imágenes utilizadas en las portadas de Grisel y Mirabella. En la parte superior figuran las damas que disputan con Torroella, pero aquí conversando con dos caballeros. En la viñeta inferior se representa la figura de Torroella presente en Grisel y Mirabella, aunque dirigiéndose en esta ocasión a dos damas que, sentadas, le escuchan (fig. 3).

En tempranas traducciones de la obra de Flores a la lengua francesa se proporcionan portadas que divulgan la imaginería de la confrontación entre ambos sexos. Así, Le Jugement d'amour (1532), en cuyo frontispicio, aunque se pretende representar a los dos amantes, aquí rebautizados como Aurelio e Ysabel, se diría, sin embargo que, por su actitud parlamentaria, la estampa parece mostrar a los defensores respectivos de mujeres y de hombres (fig. 4).

La portada de la edición de Toledo, 1526, atribuida a Miguel de Eguía presenta una escena enmarcada por orla de motivos vegetales. En una cámara de pavimento de placas triangulares en blanco y en negro, una dama parece entregar -o recoger- una vasija a un hombre armado. Del costado derecho de éste pende un alfange; sostiene en la mano izquierda una lanza. La ropa de la dama es larga y de pliegues abundantes que se extienden y ocupan parte del suelo. El grabado no alcanza a representar con estos datos a ninguna de las parejas de la obra de Flores (fig. 5). Avanzado el quinientos, los grabados de portadas de Grisel y Mirabella adoptan una función diversa, determinados por la variedad de modelos representativos de obras de otros géneros populares que circulan en la mayoría de las imprentas. Esto se aprecia en la edición sacada en Cuenca, «en cassa de Juan de Canova a diez y seis dias del mes de março de mill y quinientos y sessenta y un año». En este ejemplar se insertan tres imágenes de poco tamaño en un mismo plano: caballero y dama que aparentan conversar. El hombre, con vestimenta corta; la dama con una amplia falda tipo verdugo. Un arbolillo, a la derecha de las figuras (fig. 6).

El frontispicio de La Historia de Grisel y Mirabella con la disputa de Torrellas y Braçayda que en 1562 sale en Burgos de la imprenta de Philippe de Junta apenas tiene «valor argumental», ya que no refleja directamente, como en las anteriores, esfuerzo alguno por relacionar imagen y texto (fig. 7).

Transcribo la descripción de Mercedes Fernández Valladares: 
Dentro de una orla arquitectónica de cuatro piezas xilográficas mostrando el entablamento, dos aves que, enlazadas por el cuello a sendos lagartos, portan en el pico una corona de laurel con un aguilucho; en las bandas laterales columnas abalaustradas y en la basa, dos niños alados que muestran la Santa Faz, tres tacos xilográficos de figurillas: galán, casas, dueña, sobre las que figuran sus nombres, en let. Gót. Grisel y Mirabella. Debajo el título: La historia de Grisel y Mirabella con la disputa de Torrellas y Braçayda. La qual compuso Juan de Flores. Con licencia. Año de M.D.LxiJ. Colofón: Burgos. En casa de Philippe de Junta. $1562^{6}$.

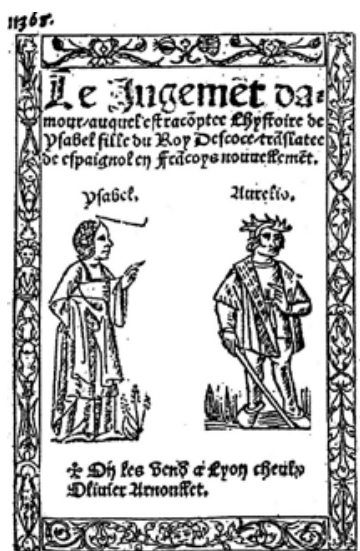

Fig. 4. Le jugement d'amour, (Lyon, O. Arnouillet, 1532), BL, 1243, aaaa3.

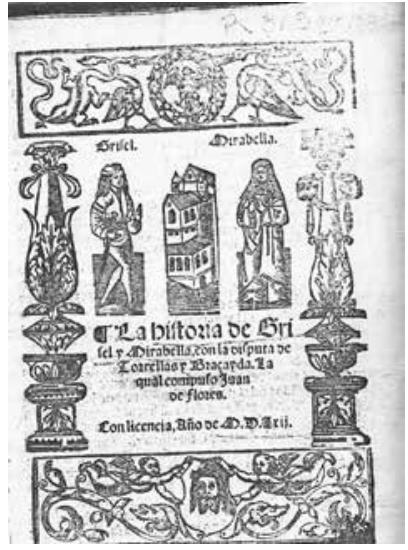

Fig. 6. Grisel y Mirabella

(Cuenca, Juan de Canova, 1561) Evora, Bibl. Pub., sec. Xvi 2725.

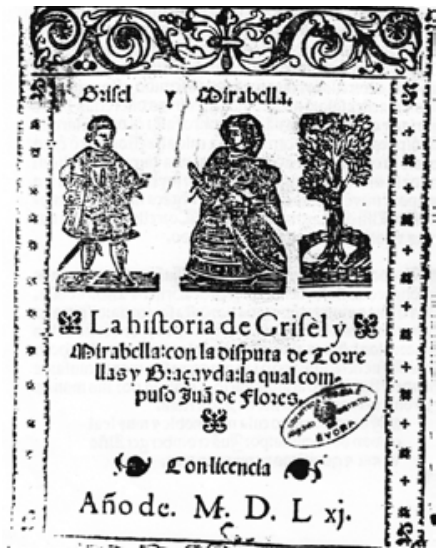

Fig. 5. Grisel y Mirabella

(Toledo, Miguel Eguía, 1526) París, BN, R. 21057.

${ }^{6}$ Mercedes Fernández Valladares, La imprenta en Burgos, II, Madrid, Arco/Libros, 2005, pp. 998-999. 
Así, pues, en este caso se relega el protagonismo de la pareja de amantes, sin utilizar grabado alguno que dé cuenta de aspectos concretos de la narración. Por el contrario, las figurillas que representan a los dos amantes de la obra de Flores proceden del ilustrativo caudal de piezas al uso de la producción popular del pliego suelto que la imprenta burgalesa heredera de Fadrique de Basilea había difundido 7 . Así, para Grisel -joven hombre tocado con bonete y que porta espada-, se echa mano de un taco utilizado en la propia oficina tipográfica de Juan de Junta para sucesivas impresiones de la Tragicomedia de Calisto y Melibea $(1531,1536)$, así como la de la Tragicomedia de Lysandro y Roselia (1542). Este taco polivalente se empleará igualmente para representar al escudero al que servirá Lazarillo en la portada de la edición de Lazarillo de Tormes (Burgos, Juan de Junta, 1554). Por otra parte el motivo de la orla inferior de esta edición de Grisel y Mirabella de 1562 -la santa faz de Cristo sostenida por dos ángeles- se había empleado en La historia de la Reina Sebilla en su edición de 1551.

En la portada de la primera edición conocida de Diego de San Pedro, Tractado de amores de Arnalte y Lucenda (Burgos, Fadrique Alemán, 1491), ante el fondo arquitectónico de una ciudad, un hombre tocado con bonete entrega una escritura a otro, destocado, y que va caminando. Al fondo, una dama de largos cabellos extendidos fuera de la ventana parece representar el motivo del enamoramiento de Arnalte, cuando la joven Lucenda en el duelo por su padre, «en el tal auto entre las manos y los cabellos guerra cruel se pregona, todos por los hombros estendidos y derramados tenía ${ }^{8}$ (fig. 8). Años más tarde, en 1522, Alonso de Melgar, al frente de la imprenta de su suegro Fadrique, emplea otra portada para la misma obra, en la que en una estancia abierta a una balconada, un caballero arrodillado entrega a una dama una flor que aparenta ir envuelta en un mensaje (fig. 9). Algunas traducciones y adaptaciones francesas de esta obra incluyen grabados convencionales en lugares que no siempre se adaptan ni reflejan el contenido concreto del texto, al servirse de un grabado muy común de portada y válido para obras diversas ${ }^{9}$ (figs. 10 y 11$)^{10}$.

${ }^{7}$ Véase Mercedes Fernández Valladares, «Biblioiconografía y literatura popular impresa: la ilustración de los pliegos sueltos burgaleses (o de babuines y estampas celestinescas)», en eHumanista, 21 (2012), pp. 87-131, especialmente p. 108, nota 34.

${ }^{8}$ Diego de San Pedro, Tractado de amores de Arnalte y Lucenda y Sermón, edición, introducción y notas de Keith Whinnom, Madrid, Castalia, 1973, p. 102.

${ }^{9}$ Es el caso de la figura 10.

${ }^{10}$ El primero pertenece a la adaptación de Denis Janot, L'Amant maltraicté de s'amye, Paris, 1541 . En cuanto a el Petit Traité de Arnalte e Lucenda, Paris, 1546, es adaptación de Jean Longis y ve la luz en el taller de la impresora Jeanne de Marnef. 


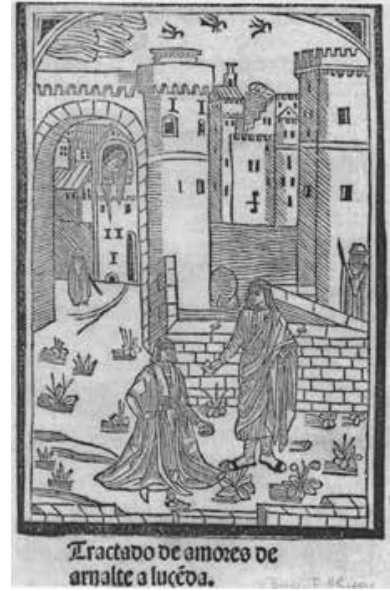

Fig. 8. Arnalte y Lucenda,

(Burgos, Fadrique Alemán, 1491), RAH, Inc. 153.

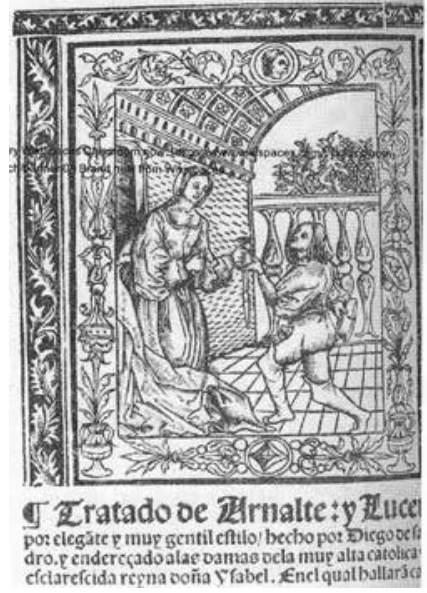

Fig. 9. Arnalte y Lucenda, (Burgos, Alonso de Melgar, 1522), BL, C.63.g.16.

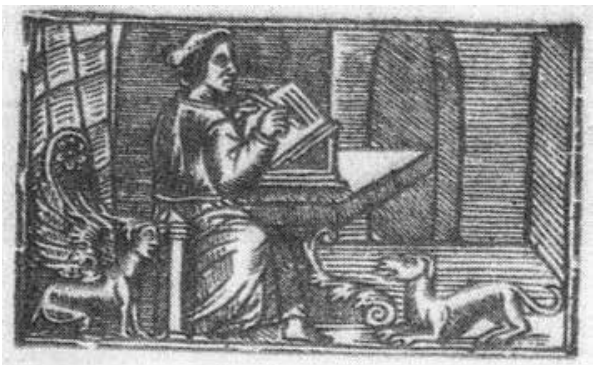

Fig. 10. L'amant maltraicté

(París, Denis Janot, 1541), Vienne, NB, 39.K.34.

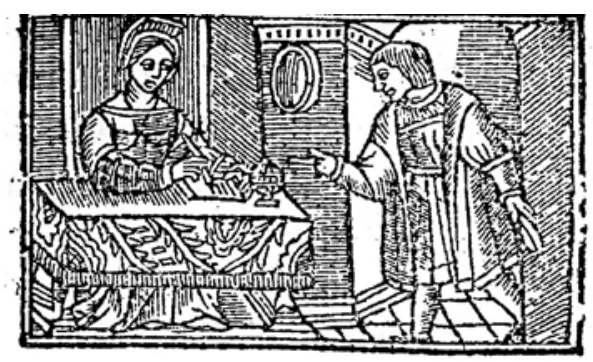

Fig. 11. Arnalte et Lucende

(París, Jeanne de Marnef, 1546), BNF. Rés. Y22344.

En el conjunto de la ficción sentimental la Cárcel de amor, obra representativa e influyente en este grupo literario, destacará en el último decenio del siglo XV por su pronta y fecunda difusión impresa que estuvo acompañada en muchos casos de una cuidadosa inserción de variadas imágenes, generalmente bien adaptadas a las circunstancias narrativas de la obra ${ }^{11}$. No lleva grabado alguno la primera edición conocida (Sevilla, Cuatro compañeros alemanes, a tres días de março de 1492) ${ }^{12}$, pero un año más tarde, casi simultáneamente en

${ }^{11}$ Remito al cuidadoso estudio de Juan Manuel Cacho Blecua, al que habré de referirme más adelante, «Los grabados de la Cárcel de Amor (Zaragoza, 1493, Barcelona, 1493, y Burgos, 1496): la muerte de Leriano», en Actas del XI Congreso Internacional de la Asociación Hispánica de Literatura Medieval (Universidad de León, 20 al 24 de septiembre de 2005), I, León, Universidad de León, Secretariado de Publicaciones, 2007, pp. 367-379.

${ }^{12}$ Consúltese el trabajo de Alan Deyermond, en el que cuidadosamente expone datos relativos a la posible pérdida de un grabado de portada en la primera edición conocida de la Cárcel de amor (Sevilla, 1492): «The Woodcuts of Diego de San Pedro's Cárcel de amor, 1492-1496», en Bulletin Hispanique 
Zaragoza, en la imprenta de Pablo Hurus (3 de junio de 1493); en Barcelona, Hans Rosenbach (18 de septiembre de 1493), «en estil de valenciana prosa» y en Burgos, Fadrique Biel (27 de octubre de 1496) sale la obra de San Pedro con el ingrediente novedoso de un conjunto de imágenes ilustrativas del texto, algunas de ellas de excelente factura ${ }^{13}$.

Por tanto, la obra tal vez más representativa e influyente en el grupo sentimental irrumpirá en el siglo XVI con un nutrido bagaje de imaginería tipográfica, producto de la colaboración interpretativa de los sucesivos grabadores. Es sabido que idénticas imágenes circulaban al mismo tiempo en las primeras imprentas para ilustrar diversos tipos de obras. Sirva como ejemplo adecuado, entre otros, el hallazgo de una Celestina (Tragicomedia de Calisto y Melibea, Zaragoza, 1507), publicada por el impresor Jorge Coci, en donde en la portada figura un improvisado grabado tomado del cuerpo de imágenes de la Cárcel de amor de Diego de San Pedro. Así, un caballero, arrodillado, con bonete en su mano derecha, y una dama, sentada, parecen conversar. Debajo figuran sendas leyendas: (Calisto) (Melibea) ${ }^{14}$ (fig. 12). No se halla actualmente este grabado «de varios usos» en la reencontrada edición de Pablo Hurus (1493), devastada por las inclemencias de cinco siglos de prisión archivera, pero sí se conserva en las de Hans Rosenbach (1493) y Fadrique Biel (1509) ${ }^{15}$. Jorge Coci, natural de Constanza, impresor avencidado en Zaragoza había sido discípulo y socio de Pablo y Juan Hurus, a los que en 1499 compró la empresa en compañía de Leonardo Hutz y Lupo Appenteger. Esta sociedad duró hasta 1504, en que Coci, solo, continuó su trabajo de impresor, llegando a ser un cualificado impresor en Aragón y «maestro de la imprenta de Zaragoza», «señor de la imprenta», como se le reconoce por sus

104:2 (2002), pp. 511-528. Asimismo, en la consideración de los grabados de la Cárcel de amor de las primeras ediciones, léase Emily C. Francomano, «Re-reading woodcut illustration in Cárcel de amor 1493-1496», en Titivillus. Revista Internacional sobre Libro Antiguo, 1 (2015), pp. 143-156.

${ }^{13}$ Desconocida la edición de Hurus, el hallazgo del perdido ejemplar se debe a Miguel Ángel Pallarés, La Cárcel de amor de Diego de San Pedro, impresa en Zaragoza el 3 de junio de 1493: membra disjecta de una edición desconocida, Zaragoza, Centro de Documentación Bibliógráfica Aragonesa, 1994. Remito al imprescindible comentario de M. ${ }^{\text {a }}$ Carmen Marín Pina, «La Cárcel de amor zaragozana (1493), una edición desconocida», en Archivo de Filología Aragonesa, 51 (1995), pp. 75-88, así como al análisis iconográfico de Juan Manuel Cacho Blecua, «Los grabados de la Cárcel de Amor (Zaragoza, 1493, Barcelona, 1493, y Burgos, 1496): la muerte de Leriano», art. cit.

${ }^{14}$ Remito a Un Volumen Facticio de Raros Post-Incunables Españoles, coordinado por Julián Martín Abad, Toledo, Antonio Pareja 1999, [Portada: Abajo se lee: (Calisto) (Melibea)].

${ }^{15}$ Véase Clive Griffin, "Celestina's Illustrations», en Bulletin of Hispanic Studies, 78 (2001), pp. 59-79. No pasó desapercibida esta reutilización de la imagen a Juan Manuel Cacho Blecua, «Iconografía amadisiana: las imágenes de Jorge Coci», en eHumanista 16 (2010), pp. 1-27; véase p. 10. Consúltese igualmente la oportunidad de este «grabado de varios usos» en Fernando Carmona Ruiz, «La cuestión iconográfica de la Celestina y el legado de Hans Weditz», en eHumanista, 19 (2011), pp. 79-112. 


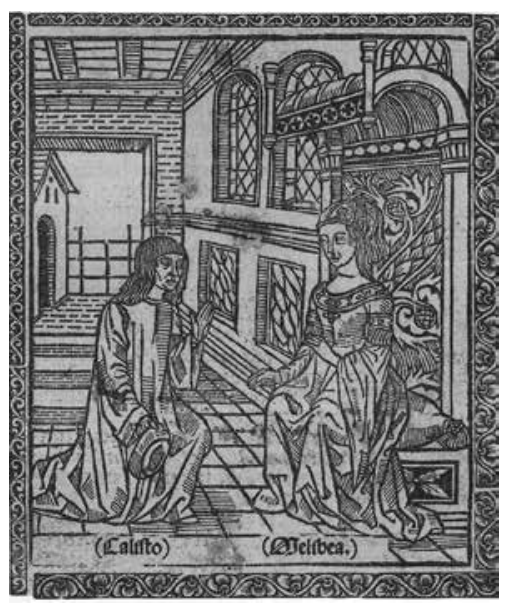

Fig. 12. La Celestina, (Jorge Coci, Zaragoza, 1507)

Toledo, Bibl. Cigarral del Carmen.

contemporáneos en la documentación conservada $^{16}$. La improvisación de la imagen en el ámbito celestinesco da cuenta de la viabilidad y flexibilidad en el empleo del material xilográfico en los talleres, ya que si la examinamos en el cuerpo de grabados de las primeras ediciones de la Cárcel de amor, podrá constatarse que en el propio taller de Jorge Coci se ha suplantado, a favor de la Tragicomedia de 1507 al auctor y auxiliar del caballero Leriano en trance de ganar para éste el afecto de la princesa Laureola. En la Cárcel de Hans Rosenbach y Fadrique Biel se representa esta escena de requerimiento amoroso por persona interpuesta, esto es, por el eficiente auctor, mientras que en la utilización celestinesca, citada más arriba, se interpreta como un encuentro entre los amantes ${ }^{17}$. Ahora bien, en los grabados de la Cárcel de amor -Hurus, Rosenbach, Biel y el propio Jorge Coci-, las figuras de Leriano y del auctor se distinguen por las vestiduras. Leriano está representado con bonete y ropa corta en el arranque de la obra, cuando va arrastrado por el salvaje Deseo. Con igual atavío y sentado ante un escritorio se prodiga para el caballero Leriano la imagen divulgadísima -en tantas obras-del estudioso o escribiente ante su pupitre. Es el auctor normalmente -confidente y hábil auxiliar de Leriano- quien viste ropa talar en todas sus representaciones. El ejemplo que se ofrece en la Tragicomedia salida de las prensas de Coci pone de manifiesto la flexibilidad en el dinamismo y aplicación diversa de ciertos grabados en el circuito impresor, en esta muestra de imágenes intercambiables entre La Celestina y la Cárcel de amor.

\footnotetext{
${ }^{16}$ Véanse Manuel José Pedraza García, La producción y distribución del libro en Zaragoza, Zaragoza, Institución Fernando el Católico (CSIC), 1997, p. 211. Del mismo autor, «El traspaso de la imprenta de Pablo Hurus: aportación documental para el estudio de la imprenta incunable en Zaragoza», en Boletín del Museo e Instituto Camón Aznar, 68 (1997), pp. 131-142 y los Documentos para el estudio de la historia del libro en Zaragoza entre 1501 y 1521, Zaragoza, Centro de documentación bibliográfica aragonesa, 1993, núms. 1366 y 1368, p. 298, núm. 1392, p. 302, así como «El grabado en Aragón en la Edad Media», en La miniatura y el grabado de la Baja Edad Media en los archivos españoles, coord. por María del Carmen Lacarra Ducay, Zaragoza, Institución «Fernando el Católico» (CSIC) -Excma. Diputación de Zaragoza, 2012, pp. 75-101. Consúltese igualmente Miguel Ángel Pallarés Jiménez, La imprenta de los incunables de Zaragoza y el comercio internacional del libro a finales del siglo XV, ob. cit., pp.147-157.

${ }^{17}$ Que el material de la imprenta de Hurus se reutilice en la de Coci es un procedimiento normal y muy común en la industria tipográfica, ya que, en caso de venta o traspaso, el utillaje y todo tipo de material de los talleres pasaba normalmente a manos del nuevo maestro.
} 
Hay referencias de dos perdidas Cárceles supuestamente salidas de la imprenta de Jorge Coci en 1511 y 1516, lo que no debe desestimarse sin más, ya que en tales momentos los talleres de Jorge Coci están en su apogeo ${ }^{18}$. El eficiente tipógrafo mantuvo muy pronto beneficiosas relaciones con algunos impresores de renombre e importancia, ya que en 1507 imprime una versión abreviada de las Introductiones (Pueriles introductiones) proporcionada por Arnao Guillén de Brocar, privilegiado impresor de la producción nebrisen$\mathrm{se}^{19}$. Aunque el grosor de la producción de Coci constituye material encargado por la Iglesia, determinante y decisiva clientela de los primeros impresores, de su imprenta saldrá la primera edición de Amadís de Gaula (1508) o primicias de tanta enjundia como la obra de Hugo Veri, Nova distichorum Verini (1510). Con equipo e instrumental de Hurus, del taller de Coci saldrá el Cancionero de todas las obras de Juan del Enzina (1516). En 1520 imprime las Décadas de Tito Livio. Philippe Berger ha insistido en las dificultades de la imprenta española en el primer decenio del siglo, por la competencia del mercado editorial europeo, coto cerrado para la producción de obras en lengua latina, normalmente extensas y, por ello, caras y prestigiosas ${ }^{20}$. Con todo, la producción de Coci en esos primeros años del siglo no parece acusar los efectos de la crisis ${ }^{21}$.

A seis días de agosto de 1523 sale de sus prensas: Cárcel de amor compuesto por Diego de sant Pedro a pedimiento del señor don Diego hernandez alcayde de los donzeles y de otros caualleros cortesanos: Nuevamente historiados y bien correydo. Va acompañado de «otro tratadillo»: la continuación interpretativa de Nicolás Núñez sobre la obra de San Pedro; es decir, sobre otro «tratado $»^{22}$. Conviene tener en cuenta el énfasis y el apunte de la reite-

${ }^{18}$ Ivy A. Corfis, Diego de San Pedro’s Cárcel de Amor, London, Tamesis Books, 1987, pp. 24 y 26-27. De la edición de 1516 da cuenta Nicolás Antonio, Bibliotheca Nova, I, p. 308 .

${ }^{19}$ Pedro M. Cátedra, «Arnao Guillén de Brocar, impresor de las obras de Nebrija», en El libro en Palacio y otros estudios bibliográficos, coord. por Pedro M. Cátedra García y M. a Luisa López-Vidriero, Salamanca, Universidad de Salamanca, 1996, pp. 43-80.

${ }^{20}$ Remito a Philippe Berger, «La evolución de la producción editorial española entre 1501 y $1520 »$, en El Libro Antiguo Español: actas del Primer Coloquio Internacional (Madrid, 18 al 20 de diciembre de 1986), coord. por Pedro Manuel Cátedra García y M. ${ }^{a}$ Luisa López-Vidriero, Salmanca, Universidad de Salamanca, 1988, pp. 63-72 y «Del manuscrito a la imprenta: inercia y sinergia», en Bulletin Hispanique, 106:1 (2004), pp. 143-159.

${ }^{21}$ Véase esta relación -no completa- de obras salidas en su taller en la etapa señalada por Berger: Confessionale de Antonino de Florencia, 1499; Officio quotidiana sive Horas, 1500; Constitutiones Synodales Archiepiscopatus Cesauraugustani, 1500; Carmen Paschali, 1500; Suma de paciencia, 1505, Las Trescientas de Juan de Mena, 1506, Libro de albeytería, 1506; Tragicomedia de Calisto y Melibea, 1507, Amadis de Gaula, 1508; Philosophía moral de Aristóteles, 1509; De primis Aragoniae regibus et eorum rerum gestarum per brevi narratione, 1509; Nova distichorum Verini, 1510; Regula novae per capitulum sedis eclesiae Cesaraugustane, 1510.

${ }^{22}$ El ejemplar en la BNE, U/687. La edición conjunta de las obras de San Pedro y de Núñez viene 
ración de las imágenes, ya que, al tiempo de declarar paladinamente que se entrega un texto bien correydo, se subraya, se acentúa la importancia de la imagen como constitutivo esencial para acompañar la invención. Ahora bien, en el cumplimiento de tal requisito se proporcionará al público lector una galería de imágenes sampedrinas que, por tamaño y descripción ambiental resultan opuestas a las desplegadas desde los últimos años del siglo anterior en las prensas florecientes de los primeros maestros impresores, que en la década de los noventa venían divulgando las muestras de un ensayismo amoroso gestado desde cuarenta años atrás.

Son idénticas las ilustraciones de las portadas de la Cárcel de Amor en las ediciones de Rosenbach y Fadrique Biel -algo distante la de Cromberger-23, al plasmar la subida del auctor -el auxiliar de Leriano- a la torre, lugar de tormento y de expresividad fundamental en la fábula para interpretar la pasión del amante Leriano; lugar ascensional y pleno de sentido que determinará la actitud del viajero y su fidelidad a Leriano hasta la muerte de éste ${ }^{24}$ (figs. 13-14).

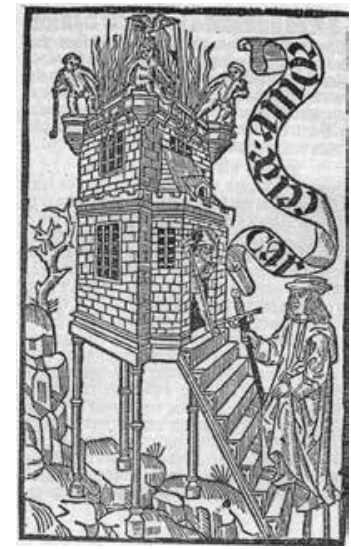

Fig. 13. Cárcel de amor (Burgos, Fadrique Biel, 1496) BL, IA 53247.

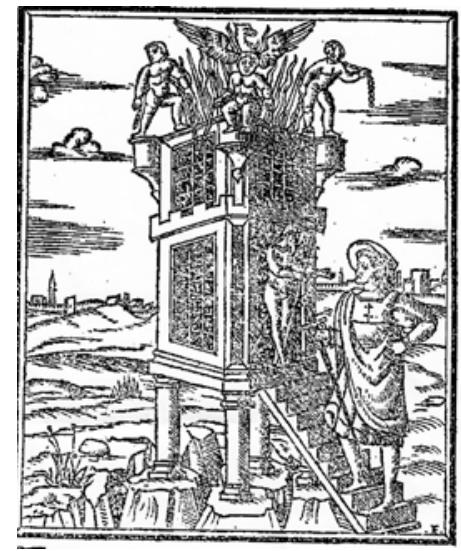

Fig. 14. Cárcel de amor (Jorge Coci, Zaragoza, 1523), BNE, U/687.

prodigándose desde Burgos, Fadrique Biel, 1496.

${ }^{23}$ En la edición de Cromberger (Sevilla, 1509), la escena se enfoca desde el lado izquierdo en donde se sitúa la figura de un auctor de aspecto diferente al de las otras ediciones.

${ }^{24}$ Estas portadas muestran un valor significativo geométrico estimado como estructura elemental y lógica, en la que la figura del auctor alcanza expresividad por su valor y buena voluntad. Una imagen ascensional con elementos muy similares se halla en el Liber de ascensu et descensu intelectum de Ramón Llull, 1512. En esta portada de la edición de Coci $(120$ x $95 \mathrm{~mm})$ figura una $\mathrm{F}$ en el ángulo inferior derecho del folio; es posible que portada y estampas del texto correspondan a manos distintas. En el cuerpo de la obra, la figura del auctor no se identifica con la imagen de la portada. Lyell dedicó un capítulo especial para la producción aragonesa, deteniéndose en el comentario de algunas ilustraciones de Coci. Estima como «interesante» esta portada. Véase James P. R. Lyell, La ilustración del libro antiguo en España, edición y prólogo de Julián Martín Abad, Madrid, Ollero \& Ramos, 1997, pp. 161-186, referencia p. 162. 
En esta ilustración inicial, en los dos grabados se precisan los cuatro pilares que sostienen la torre: muy estilizados en el grabado de Fadrique Biel y, por tanto, en el de Hurus y Rosenbach. En Cromberger y Coci los pilares se trazan cortos y de mayor grosor. El remate del edificio se plasma en las tres portadas de modo similar, aunque con algunos matices: un águila, alumbrada por las llamaradas que salen de la torre, preside un conjunto de tres figuras humanas -aunque solo dos en el impreso de Cromberger- que sostienen cadenas. A diferencia de otros frontispicios, en el de Coci el auctor que sube las escaleras que conducen a la torre porta espada y lleva vestidura corta, medio cubierta por un manto que se recoge en el hombro derecho; va tocado por una gorra de vuelta entera, sencilla y sin cortes. En la portada de Biel el auctor lleva ropa talar.

Destaca la actitud del guardián de la torre, más expresiva que en otros grabados; situado completamente fuera de la puerta, tendida su mano izquierda, como si la representación gráfica pretendiese transmitir: «Las armas que te pido y te conviene dexar son [...] Descanso y Esperança y Descontentamiento ${ }^{25}$. Igualmente hay una diferencia notable en la representación del paisaje de fondo entre el grabado del impreso de Coci y los anteriores. Diego de San Pedro situaba la torre en un primer plano y «en lo más alto de la sierra». En el grabado de Coci la torre emerge en medio de un campo: «la lumbre del día descubrió los canpos», y tiene como fondo paisajístico un plano vertical dividido en dos segmentos de idénticas proporciones: en el segmento inferior y en lejanía se representa una extensa ciudad amurallada y con edificios varios: iglesia torres, casas. En el plano superior que parece dominar la escena, un cielo con grupos de nubes. No hay apenas dimensión paisajística en el resto de las portadas; únicamente representan en un primer término un espacio mínimo de terreno en el que se fundamenta la torre.

Es, por el contrario, menos expresiva en el impreso de Coci la plasmación del trascendental y determinante encuentro del caminante con la comitiva que lleva a Leriano a esa «cárcel de Amor, donde con solo morir se espera librar», aun cuando en una y otra viñeta se hallan todos los elementos fundamentales que proporcionó San Pedro ${ }^{26}$ (figs. 15-16).

${ }^{25}$ Diego de San Pedro, Cárcel de Amor, edición prólogo y notas de Carmen Parrilla (y Keith Whinnom para la «Continuación» de Nicolás Núñez), Barcelona, Crítica, 1995, p. 7.

${ }^{26}$ Me permito agregar mínimos datos a la observación de Harvey Sharrer, «La Cárcel de amor de Diego de San Pedro: la confluencia de lo sagrado y lo profano en "la imagen femenil entallada en una piedra muy clara"», en Actas del III Congreso Internacional de la Asociación Hispánica de Literatura Medieval, ed. de María Isabel Toro Pascua, Salamanca, Biblioteca Española del siglo XV-Departamento de Literatura Española e Hispanoamericana, 1994, pp. 983-996. 


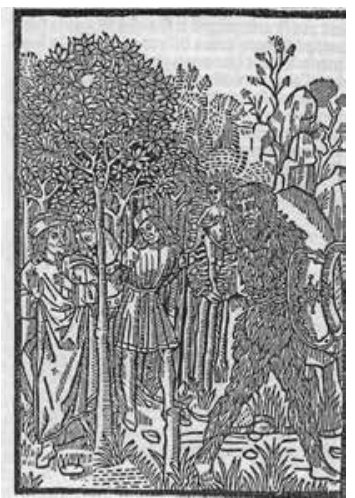

Fig. 15. Cárcel de amor (Jorge Coci, Zaragoza, 1523), BNE, U/687.

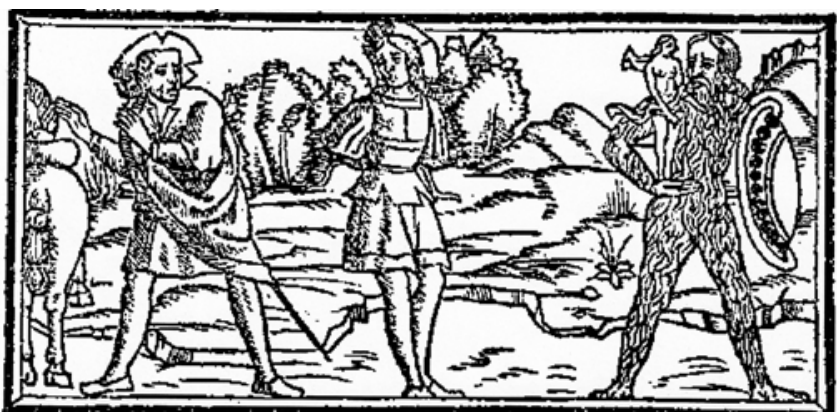

Fig. 16. Cárcel de amor (Jorge Coci, Zaragoza, 1523), BNE, U/687.

Frontalmente y, en un mismo plano, en el grabado del impreso de Coci $(95 \times 50 \mathrm{~mm})$ se han trazado las figuras, pero no ante el paisaje selvático que requiere la composición y que con fino dramatismo se representa en Barcelona, 1493, sino en una llanura que tiene como telón de fondo ciertos matorrales que no alcanzan a representar el lugar requerido que trazó San Pedro: «unos robledales» y que, por el contrario, recreaba con acierto el grabado catalán. En el grabado de Coci, Deseo está representado con sus atributos: cuerpo cubierto de vello, escudo. Sin embargo, la figurina de la mujer prácticamente desnuda que sostiene en la palma de su mano derecha, carece de los rayos aureolados que se plasman en el grabado de 1493. Con su mano derecha la mujer se cubre con una muy estrecha franja de tela, mientras que su mano izquierda reposa sobre la parte superior del pecho del salvaje. Esta pequeña Venus no vuelve el rostro hacia el prisionero, como se aprecia en los otros impresos, sino hacia el salvaje $\mathrm{e}^{27}$. Con trazados menos firmes y logrados, la figura de Leriano, maniatado y con rostro doliente, se asemeja en lo fundamental a la figura del grabado de 1493. Para la figura del auctor, en el margen izquierdo de la página, se ha trazado un gesto asombrado y temeroso. Detrás de él asoma la cabeza de su caballo; curiosamente en este grabado de Coci también se representa un equino, pero no de frente, como se aprecia en los otros impresos, sino de ancas.

${ }^{27}$ Finamente, Harvey Sharrer ha manejado varias interpretaciones para la «imagen feminil entallada en una piedra muy clara», desde la evocación de Venus influyente con reminiscencias dantescas de la Vita nuova, según Dante, hasta la interpretación sacroprofana de la Virgen María en el seno de la mandorla, según se muestra escultóricamente en el templo cristiano, sin descartar la convencionalidad de este tópico escénico de carácter sacroprofano. 
De acuerdo con los avatares de la historia que se cuenta, el lector de las anteriores ediciones de la obra de San Pedro contemplaba por medio de los grabados el valor ornamental de los espacios predominantes y adecuados para situar espacial e ideológicamente la ficción narrativa: estancias de palacio, corte real, movimiento de tropas. Veinte años más tarde, en la Cárcel que sale de las prensas de Jorge Coci se modera la perspectiva ambiental y se propone una imaginería que hurta al lector la ilusión arquitectónica de los interiores en los gótico-renacentistas grabados de los primeros impresores, esbozados ahora sencillamente con objetos esenciales meramente identificadores del lugar escénico. El contraste es notable; las estampas de esta edición de Coci que pocos años años más tarde acompañarán sucesivas tiradas de la Cárcel en lengua castellana tanto en España como en Italia, se diferencian rotundamente de la iconografía de las ediciones anteriores ${ }^{28}$.

En conjunto, las ilustraciones, en número de veinticuatro, se disponen ocupando horizontalmente toda la caja de la escritura. Una mayoría -12- se insertan en la parte superior del folio. Las doce restantes se agrupan en número de seis respectivamente en la parte media y en la inferior, encabezando siempre un apartado o capítulo. Predomina el perfil en la representación de la figura humana; solamente en seis grabados las figuras se disponen de frente. En otros ocho se alternan frontalidad y perfil. Cuatro de ellos $(95 \times 50 \mathrm{~mm})$ representarán una sola escena: el encuentro del auctor con la comitiva que lleva a Leriano, y otra escena repetida en tres ocasiones para figurar a éste hablando con el auctor. De estas tres, la primera, siguiendo el orden narrativo, se inserta al tiempo que Leriano, sufriendo los tormentos de la cárcel, habla con su auxiliar:

Tu venida aquí yo la causé $[\ldots]$ de los misterios que ves quiero informarte; la causa de mi prisión quiero que sepas; que me delibres quiero pedirte si por bien lo tovieres ${ }^{29}$.

Sin embargo, la imagen no se corresponde con el contenido, ya que la escena se encuadra en una estancia con dos ventanas y suelo ajedrezado, sin traza alguna de representar la siniestra sala en que Leriano se encuentra, aun cuando un título reza: «El preso al auctor» (fig. 17). Esta misma estampa se reproduce en otras dos situaciones en las que el auxiliar ha de comunicar a

\footnotetext{
${ }^{28}$ Véase al respecto, Juan Manuel Cacho Blecua, «Los grabados de la Cárcel de Amor (Zaragoza, 1493, Barcelona, 1493, y Burgos, 1496): la muerte de Leriano», art. cit., p. 368, nota 4.

${ }^{29}$ Diego de San Pedro, Cárcel de Amor, ed. cit, pp. 8-9.
} 
Leriano información relativa a la actitud de Laureola y a los vaivenes del negocio amoroso ${ }^{30}$.

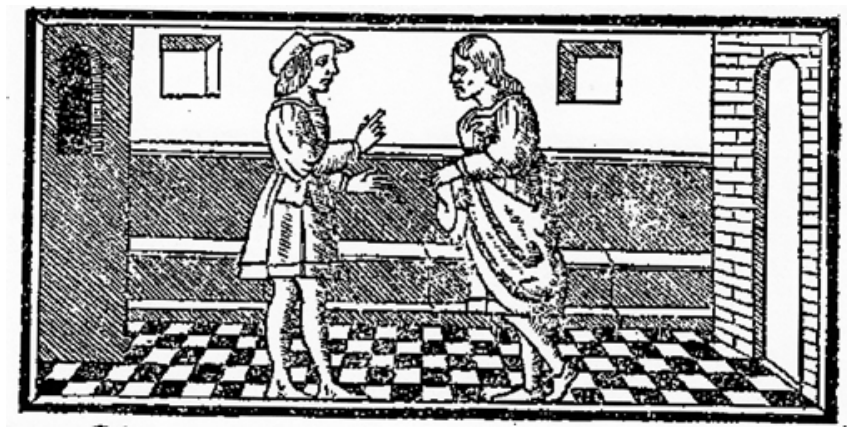

Fig. 17. Cárcel de amor (Jorge Coci, Zaragoza, 1523), BNE, U/687.

El resto del material gráfico consiste en veinte parejas de pequeñas viñetas $(4,8 \times 4,7 \mathrm{~mm})$ consecutivas al orden del relato. De estas cuarenta imágenes resultantes son únicas diecisiete estampas; el resto es material reiterativo. En la primera sección se suceden las imágenes que transmiten el empeño de Leriano, quien deposita su esperanza en la gestión del auctor. La primera escena desarrollada en dos viñetas emparejadas comienza en el segundo cuadernillo: teniendo como fondo una simple y casi desnuda habitación, el emisario, de rodillas, traslada verbalmente a Laureola la solicitud de Leriano; la princesa, de pie, en actitud de reprimenda, levanta el brazo y blande un índice acusatorio. La viñeta emparejada con esta primera tiene categoría de única en toda la serie y muestra una pintoresca reacción consecutiva que describe la sorpresa y confusión de la princesa - ¿tal vez también desagrado?-, al representarla sola, de frente y con los brazos puestos en jarras (figs. 18-19).

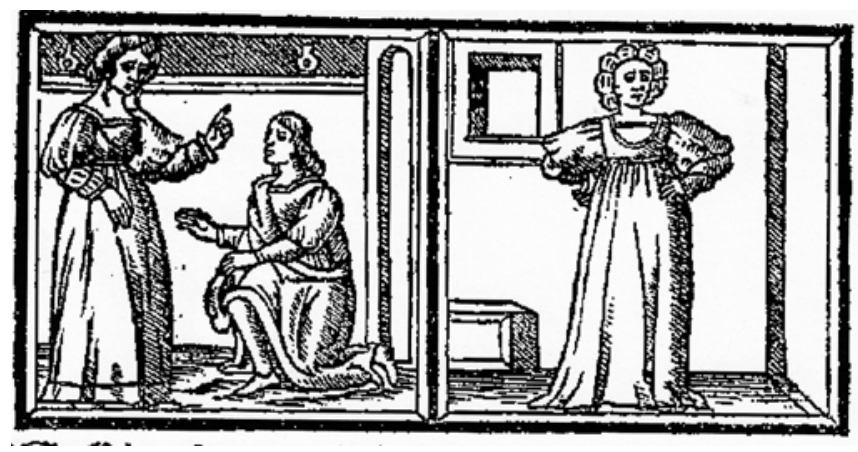

Figs. 18-19. Cárcel de amor (Jorge Coci, Zaragoza, 1523), BNE, U/687.

\footnotetext{
${ }^{30}$ A pesar de la cuidadosa descripción del lugar de tormento de Leriano, en ninguna de las ediciones conocidas de la Cárcel se plasma la escena cruenta del mártir de amor.
} 
La llamativa ilustración no está en desacuerdo con las manifestaciones de la princesa al intemediario, ya que San Pedro ha puesto en boca de Laureola amenazas de muerte. Así el auctor apunta: «su habla, vi, aunque fue corta en razón, que fue larga en enojo». El orden expresivo de este tipo de grabados sustenta a lo largo del relato los vericuetos de una requesta y, por ello, la repetición de actitudes, a causa del trasiego de razonamientos verbales o epistolares, pero la postura trazada para la princesa-brazos en jarras- es única en la serie de estos grabados.

Generalmente las ilustraciones emparejadas se vinculan ofreciendo el desarrollo de una acción conjunta, siguiendo cuidadosamente el hilo narrativo. Las imágenes utilizadas para el trasiego de recados tendrán siempre como fondo la simple y casi desnuda habitación: Laureola de pie, mientras el auctor, de rodillas, entrega o recibe el mensaje. Lo mismo sucede para comunicarse Leriano con su auxiliar: se traza una escena en que Leriano y auctor, presentados de perfil, intercambian sus recados (figs. 20-21 y 17).

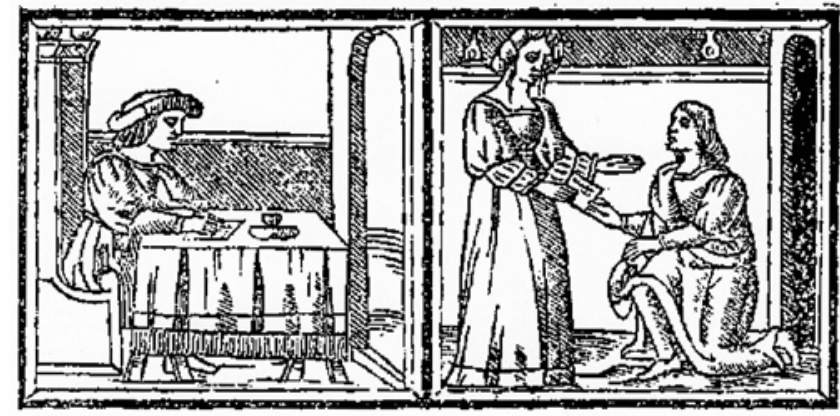

Figs. 20-21. Cárcel de amor (Jorge Coci, Zaragoza, 1523), BNE, U/687.

La vestimenta de las figuras masculinas se ajusta a la indumentaria del primer tercio del siglo XVI. Leriano viste ropa corta; una especie de sayuelo ceñido a la cintura y que se prolonga hasta las rodillas, ampliando su volumen por medio de nesgas. En la cabeza una gorra sencilla, pero con vuelta o ala doblada, no acuchillada. En los grabados de las ediciones anteriores todos los varones, incluido Leriano, se cubren con bonete ${ }^{31}$. El auctor, descubierta la cabeza, viste un ropón que acompaña con manto, el cual recoge en su brazo cuando, de pie o arrodillado, se dirige a Laureola o a Leriano. Generalmente Laureola viste un sencillo vestido largo rematado en el pie por una alforza; escote cuadrado, cuerpo ajustado, talle alto y bocamangas acuchilladas, que son su único adorno. En la llamativa viñeta en que la princesa, con los brazos

\footnotetext{
${ }^{31}$ Véanse figs. 22 y 30. La distinción de estos usos tal vez esté marcada por el tiempo transcurrido -casi un cuarto de siglo- entre las primeras ediciones de la Cárcel y ésta salida en 1523.
} 
en jarras, parece manifestar sorpresa o desagrado, su vestido, aunque sencillo, tiene mayor amplitud que el que aparece en el resto de las estampas y también más longitud, ya que arrastra sobre el pavimento, sin alforza alguna como remate. En esta única imagen la princesa parece llevar una especie de tocado en forma de diadema o rollo que aparenta gruesos bucles. En el resto de las viñetas los bucles rodean la cabeza de Laureola, pero con un trazado más desvaído. Este peinado o tocado femenino se halla en la portada de la edición de la Tragicomedia de Calisto y Melibea que el librero Juan Bautista Pederzano saca en Venecia, 1531 para las figuras de Melibea y de Lucrecia. Igualmente el modelo de la gorra de Calisto, de ala doblada, es similar a la gorra que cubre a Leriano en esta edición de la Cárcel de amor de 1523.

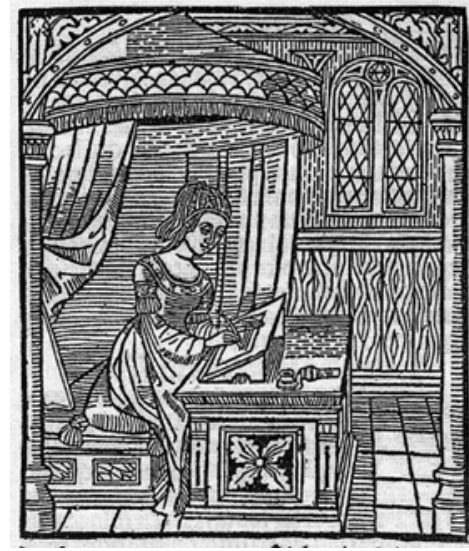

Fig. 22. Estancia de Leriano (Burgos, Fadrique Biel, 1496), BL, IA 53247.

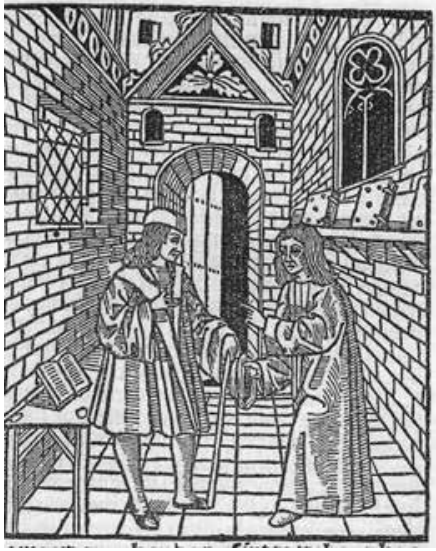

Fig. 23. Estancia de Laureola (Burgos, Fadrique Biel, 1496), BL, IA 53247.

Estos grabados de Coci carecen del aparato arquitectónico, ornamental y decorativo que habían proporcionado las anteriores impresiones de la Cárcel (Hurus, Rosenbach, Biel) en las que, con magnificencia y detallismo se encuadraban preferentemente las escenas narrativas de interiores. La estancia de trabajo de Leriano, en la que no faltan mesa y libros, y en donde recibe y alecciona al auctor, así como la cámara en donde la princesa Laureola se sienta ante un lujoso recado de escribir (figs. 22-23), no tienen parecido alguno con los interiores que se trazan en el impreso de Coci, ya que en éste las habitaciones son parcas en objetos prácticos y decorativos: una simple ventana o arco de entrada; algún sencillo friso o un estante con un par de objetos; una mesa con recado de escribir. En general, el mobiliario es muy sencillo, y esta sencillez predomina en la mayoría de las viñetas, sea cual sea el ambiente que se evoca.

Así, la corte real -representada en cuatro ocasiones- se limita a mostrar al 
rey, siempre de perfil, coronado, y sentado en un trono carente de todo adorno, similar incluso al asiento que el propio Leriano ocupa en su casa: una silla con respaldo rematado por dos pomos ${ }^{32}$. El monarca se muestra como una figura hierática -el cetro en su mano izquierda, extendido el índice de la derecha-, habla o escucha a sus súbditos, a la reina, al cardenal, recibe una carta que Laureola le escribe desde la prisión. Ahora bien, su asiento está tan poco elevado que apenas se marca la distancia entre rey y súbditos; además esta composición de perfil hurta al lector la significación directa del poder real que se había seguido y potenciado en los grabados de las primeras ediciones de la Cárcel. Esta sencillez, casi indigencia ambiental, se aprecia igualmente en el grabado que representa la visita de la reina a Laureola prisionera, lo que, comparado con el que se reprodujo en los primeros impresos de la Cárcel, transmite, eso sí principalmente, la soledad y desamparo de las dos mujeres (figs. 25, 28-29).

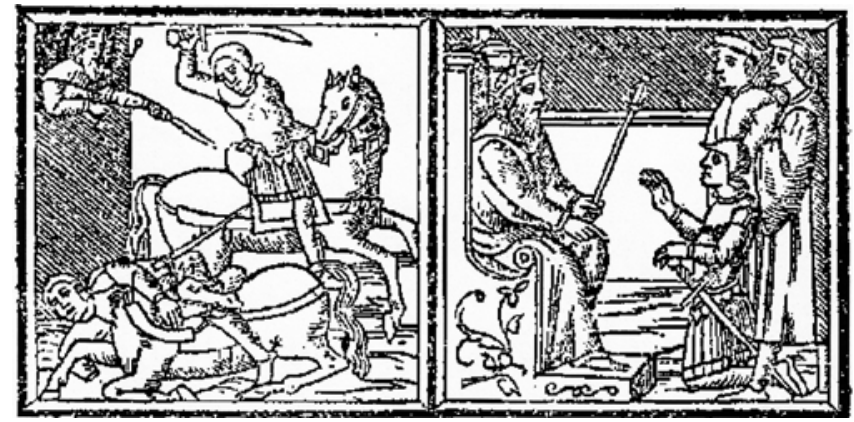

Figs. 24-25. Cárcel de amor (Jorge Coci, Zaragoza, 1523), BNE, U/687.

Mayor originalidad, atención y detallismo se aprecia en los grabados que ilustran la sección dramática de la Cárcel, a partir de la prisión de Laureola. Así, se ha plasmado con cierto rigor y, a la vez expresividad, el combate entre Leriano y Persio, ya que se ha recurrido a simultanear las acciones. Leriano, a caballo levanta su espada; Persio, vencido, se representa medio descabalgado; mutilado ya de su mano derecha, mientras que el rey -de perfil, como habitualmente-, se apresura a echar el bastón (fig. 24). Otra vez la composición de esta escena se aparta de la imagen real que se prodigaba en los grabados de Rosenbach y Biel, en donde los reyes centran con su presencia el acto: los dos caballeros luchan y el monarca muestra el bastón, pero conviene observar

${ }^{32}$ Unos rasgos florales en el lado derecho del trono diferencian los dos asientos en el grabado que representa al monarca recibiendo a Leriano después del combate contra Persio. Puede decirse que esta iconografía desmerece ante el tratamiento del aparato gráfico empleado en las ediciones anteriores de

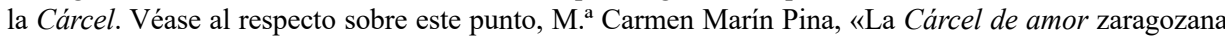
(1493), una edición desconocida», art. cit., pp. 84-85. 
que la ilustración simultánea que proporciona Coci sigue con más precisión el relato de San Pedro:

[...] puesto el rey en un cadahalso [...] vinieron los cavalleros [fuéronse el uno para el otro [...] Finalmente, por no detenerme en esto que parece cuento de historias viejas, Leriano le cortó a Persio la mano derecha [...] y como ciertos cavalleros sus parientes le viesen estrecho de muerte, suplicaron al rey mandase echar el bastón ${ }^{33}$.

A pesar de la sencillez de líneas, las viñetas que prodigan imágenes bélicas presentan ciertos rasgos cuidadosos en la plasmación de figura y actitudes. Coci divide en dos grabados consecutivos la salida de Laureola de la prisión y la pelea de la gente de Leriano con los hombres del rey, que vienen «al rebato» a impedir la libertad de la princesa, lo que en los grabados de Hurus y Rosenbach se representa simultáneamente. La sencilla viñeta que ilustra la arenga de Leriano a sus soldados, vinculada en la misma plana a la imagen circunstancial del asedio que en Susa padece su gente, es una intervención novedosa en el impreso de Coci, ya que no se halla en los grabados de las anteriores ediciones (figs. 26-27).

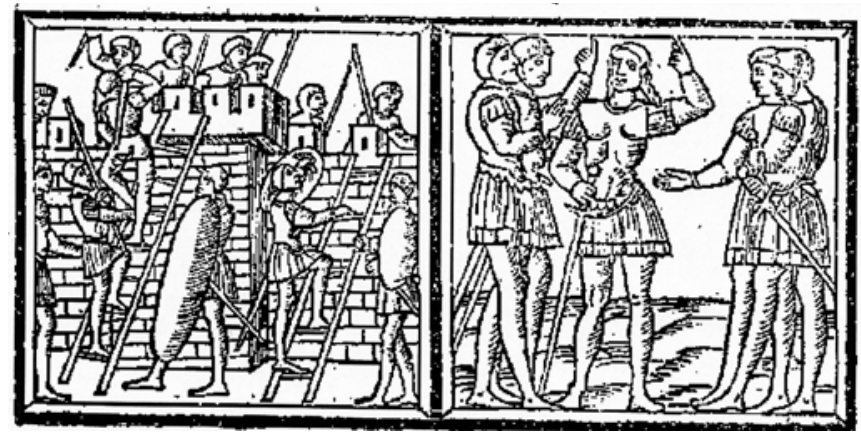

Figs. 26-27. Cárcel de amor (Jorge Coci, Zaragoza, 1523), BNE, U/687.

Sin duda, la sencillez iconográfica empleada para mostrar el tránsito de Leriano en los grabados de la edición de Jorge Coci es uno de los datos contrastivos más elocuentes en un análisis comparativo, entre los primeros grabados de la obra de San Pedro y los que se propagan veinticinco años más tarde, cuando algunos de los lectores que manejan el impreso de Coci acaso desconociesen ediciones anteriores de la Cárcel de amor. Nada más elocuente al respecto que el carácter teatral de la escena y los objetos que en ella se representan. En los canónicos grabados que anteceden a este de Coci se

\footnotetext{
${ }^{33}$ Cárcel de amor, ed. cit., p. 34.
} 
exhibe el lujoso lecho de la habitación de Leriano: una elegante pieza, mueble artístico coronado por baldaquín y situado en el centro de la estancia ${ }^{34}$.

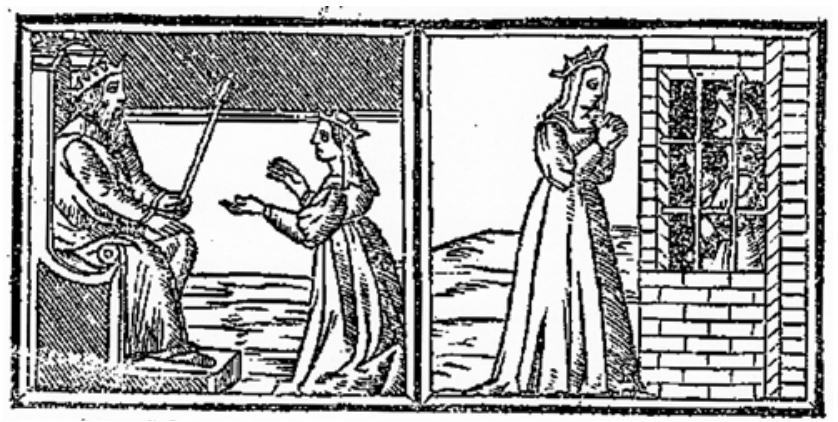

Figs. 28-29. Cárcel de amor (Jorge Coci, Zaragoza, 1523), BNE, U/687.

Por el contrario, Jorge Coci se ha determinado por un sencillo lecho en cuya cabecera destacan como remate los sencillos pomos ya empleados en otras xilografías de su Cárcel, tanto en asientos comunes como en el propio trono real. La cama de Leriano es aquí un mueble sumamente sencillo, sin adorno alguno, pero en el que, por el contrario, se destaca su utilidad, al dejar ver el arquibanco sobre el que se eleva el lecho y que sirve de acceso al mismo, de asiento, así como de espacio para guardar objetos (figs. 30-31).

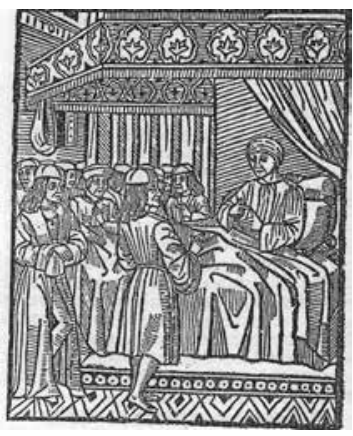

Fig. 30. (Burgos, Fadrique Biel, 1496), BL, IA 53247

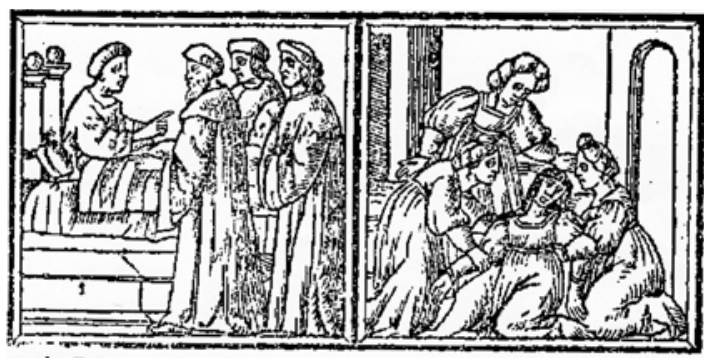

Figs. 31-32. Cárcel de amor (Jorge Coci, Zaragoza, 1523), BNE, U/687.

${ }^{34}$ Precisamente en el friso de este grabado dejó su firma Tomás Ubert, ilustrador afincado en Zaragoza, y «maestro de tallar moldes de ymagines», según ha constatado Pallarés, La Cárcel de amor de Diego de San Pedro, impresa en Zaragoza el 3 de junio de 1493, ob. cit., pp. ix, x, aportando más tarde documentación en torno a esta figura. Véase La imprenta de los incunables de Zaragoza y el comercio internacional de libro a finales del siglo XV, doc. 270, pp. 270-271. Un grabado muy similar para la estancia de Leriano se representa para el acto XIII de La Celestina en la edición de Burgos, Fadrique de Basilea, 1499, aunque reflejando el placer de Calisto, después de «aquel açucarado rato con Melibea». Consúltese Amaranta Saguar García, «The concept of Imago Agens. In Celestina: Text and Image», en Celestinesca, 39 (2015), pp. 247-274. 
Los primeros impresores han seguido fielmente en estas escenas finales la letra del texto: «Pues como por la corte y todo el reino se publicase que Leriano se dexava morir, ívanle a ver todos sus amigos y parientes». De modo que un tropel de gente rodea al agonizante, mientras que, veinte años más tarde, en este impreso de Coci el número de los circunstantes se reduce a tres. Con todo, se observará que no falta, aunque no llega al efectismo de las impresiones anteriores, la disponibilidad del índice enumerativo del caballero para -con precisión- afear y combatir el ataque de Tefeo; sin embargo, se ha prescindido de la evocativa presencia simbólica del leal can $^{35}$. Como procedimiento para simultanear las acciones de escenas contiguas, en el impreso de Coci se inserta el dolor de la madre de Leriano, asistida por tres damas, mientras que su patético y retórico llanto se sitúa como escena final y emparejado -se diría que buscando la simultaneidad- con la última acción de Leriano incorporado en su lecho y bebiendo las cartas de Laureola (figs. 33$34)^{36}$. No se plasma la decisiva figura del auctor, como testigo del tránsito de Leriano, sino que se representa la figura de un caballero, a juzgar por su ropa y gorra, con similar atuendo con el que se representa a Leriano en la mayoría de las estampas.

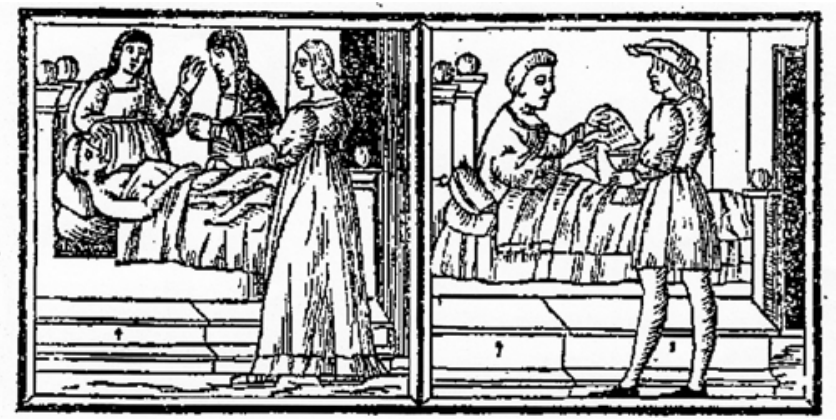

Figs. 33-34. Cárcel de amor (Jorge Coci, Zaragoza, 1523), BNE, U/687.

Así, pues, las imágenes impresas que acompañan la lectura de la Cárcel de amor salida de las prensas de Jorge Coci alcanzan a potenciar el sentido y la expresión del mensaje literario, como incremento del contenido textual, determinadas y favorecidas por la pericia con que se disponen para la comprensión de la lectura, buscando la simultaneidad de texto e imagen, aplicando la iteración

${ }^{35}$ Tal vez porque Jorge Coci no tuvo ocasión de leer el agudo e inteligente comentario de este paso en el trabajo de Juan Manuel Cacho Blecua, «Los grabados de la Cárcel de Amor (Zaragoza, 1493, Barcelona, 1493, y Burgos, 1496): la muerte de Leriano», art. cit., pp. 367-379.

${ }^{36}$ Juan Manuel Cacho Blecua reparaba en la soledad que se comunica en las dos últimas imágenes de Leriano según las ediciones anteriores, sin compañía alguna de familiares y amigos. 
necesaria de ciertas escenas, o la singularidad de algunos grabados únicos ${ }^{37}$. La modificación o el replanteamiento estético de estos grabados de Coci, tanto en lo formal como en lo ornamental, sugiere, en principio, la conveniencia de un plan de abaratamiento del producto y ello determinará una cierta oblicuidad frente a los canónicos grabados de las ediciones anteriores, de mayor calidad por su elaboración compleja y todavía a lo largo del siglo XVI, material indispensable en los talleres para diversos usos ${ }^{38}$. Aun con la posesión de tales fondos, en la imprenta de Coci se manejaban paralelamente tacos de dibujos sencillos y escuetos, frecuentemente utilizados para libros que popularizaban la devoción religiosa y, a la vez, otros grabados de mayor calidad, por su elaboración compleja ${ }^{39}$. Es evidente que una modesta plástica de dibujo sencillo se plasma en los grabados de su Cárcel de amor, sea cual sea su procedencia. Se ha optado por la expresividad de la figura humana, relegando la descripción ambiental o, al menos simplificando los rasgos decorativos ${ }^{40}$. A pesar de la diferencia formal y ornamental con los grabados de Hurus, el programa de imágenes que Coci dispone no se aparta del sistema narrativo-pictórico desarrollado por los impresores anteriores. Al fin, un texto con imágenes resultaría para algunos lectores una especie de básico premio anticipado de las presunciones, hipótesis y conjeturas que podría manejar el lector atento, según habría de postular, andados los tiempos, la estética de la recepción.

Lógicamente en Italia hubo de tener buena acogida y generosa publicación el grupo de obras representativo de los tratados de amores españoles, no sólo por el interés y patronazgo de españoles allá avencidados en tareas intelectuales o comerciales, sino por la previsión especulativa de mercaderes y libreros. Entre las obras de Juan de Flores, Grisel y Mirabella sobrevivió impresa desde 1521 hasta 1552, con una casi idéntica difusión a la que esta obra tuvo en España ${ }^{41}$. En cuanto a la Cárcel de amor, la traducción al italiano se

${ }^{37}$ Una excepción a la lograda simultaneidad de imagen y escritura en todo el impreso es el grabado que recoge la arenga de Leriano a sus hombres, situado un poco más adelante que donde correspondería.

${ }^{38}$ Como se prueba en la utilización del grabado de la Cárcel de amor para la Tragicomedia de Calisto y Melibea que Coci imprime en 1507. Mucho más tardío, en la imprenta de Juan de Junta, en Burgos (1540), y para la portada de Las preguntas que el emperador Adriano hizo al infante Epitus se utiliza el grabado de la Cárcel de amor, empleado por Hurus et alia para el pasaje en que el rey en su trono y ante la corte escucha la petición de clemencia del cardenal.

${ }^{39} \mathrm{La}$ expresividad de la figura humana de trazos sencillos, sola o en grupos, es la tónica seguida, por ejemplo, en los tacos utilizados para las Horae ad usum Romanum: Officia quotidiana, 1500 (BNE, incunable 2724), uno de sus primeros trabajos con Hutz y Appentegger. Los textos de carácter piadoso no expresan tanto el dramatismo como la devoción en algunos grabados de Coci.

${ }^{40}$ Así, María Carmen Marín, sobre esta edición anotaba que en la sustitución de modelos que propone Coci «se advierte ya una nueva estética». «La Cárcel de amor zaragozana (1493), una edición desconocida», art. cit., p. 82

${ }^{41}$ Lelio Manfredi fue el responsable de la traducción a la lengua italiana: «da M. Lelio Aletiphilo di lingua castigliana in italico idioma tradotta» (1521) y, a partir de ello, Venecia se significó como foco 280

$R P M, 30$ (2016), pp. 259-285, ISSN: 1137-8905 
debe a Lelio Manfredi, quien la traduce para Isabella d'Este en $1514^{42}$. Lelio Manfredi continuó obsequiando a la dama con versiones de otras obras que conforman el grupo sentimental.

Ahora bien, en Italia la fortuna editorial de la obra de San Pedro debe mucho a la potencia de la imprenta veneciana, atenta a las novedades y abierta para acoger obras de diferentes géneros y publicarlos en su lengua original castellana $^{43}$. La presencia de españoles en Italia en un clima benévolo cosmopolita y, a la vez, próspero, así como el interés por la lengua castellana y su producción literaria fomentó y propagó los productos en boga. Para la difusión de la Cárcel en Italia debió de ser determinante la intervención del mercader de libros Juan Bautista Pederzano que «en la librería o botecha que tiene por enseña la torre junto al puente de Rioalto» $\mathrm{y}$ «por importunación de muy muchos señores a quien la obra y estillo y lengua romance castellana muy muncho plaze», publica una Cárcel de amor, sin la continuación de Nicolás Núñez y «Corecto de las letras que tras tocadas estavan se acabo año del Señor 1531». Va provista de las mismas imágenes que se hallan en el impreso de Coci de 1523, más otras dos, aunque no nuevas, sino repetidas, a saber, la escena de la reina, arrodillada ante el rey, suplicando por Laureola, así como la visita de la propia reina a la cárcel (figs. 28 y 29). Por otra parte, este impreso promovido por Pederzano es preciso en otro tipo de información, ya que sus viñetas llevan generalmente en su parte superior una cartela indicativa de la escena que se muestra, lo que no figuraba en el impreso zaragozano (fig. 35).

impresor de las versiones al italiano: Gregorio de Gregori (1526), Melchiorre de Sessa (1529), Marchiò de Sessa (1533), Giolito de Ferrari (1533, 1543, 1548), F. Bindoni y y M. Pasini (1534). En Milán, Gianotto da Castiglio (1521); en Mantua, Venturino Rufinello (1552).

${ }^{42}$ En la dedicatoria, el erudito Aletiphilo se sirvió literalmente del ineludible tópico del exordio que San Pedro dirige al alcayde de los donceles: «Unde ancora che mi manchasse patientia per tacere / non mi manchaua cognoscimento per uedere quanto mi era meglio apretiarmi di qualchio tacessi / que pentirmi per quel chio haueuo a dire: e posto che cossi io lo cognoscessi / e che ancora ne vedessi apta la ueritate / ho seguito la opinion mia: E hauendo operato il peggio: non resto senza punitione: perche cum la vergogna satisfo a lo errore che per ignorantia ho commesso». / Carcer damore traducto dal magnifico miser Lelio de Manfredi ferrarese: de idioma spagnolo in lingua materna: novamente stampato, 1515. (BNE, R/12477).

${ }^{43}$ Una buena parte de nuestra literatura - acaso sin mucho mérito, en ocasiones- se extendió en Italia en la primera mitad del siglo XVI, acogida por el clima de interés por la lengua castellana que muchos conocían y hablaban. Connotaba - apunta Bognolo- cierto «esnobismo social», con el añadido de una etapa económicamente próspera que aseguraba las empresas editoriales. Véase, al respecto, A. Bognolo, «El libro español en Venecia en el siglo XVI» y Daniela Capra, «Edición y traducción de libros españoles en la Venecia del siglo XVI», en Rumbos del hispanismo en el umbral del Cincuentenario de la AIH, coord. por Patrizia Botta, III, ed. de María Luisa Cerrón Puga, Roma, Bagatto Libri, 2012, pp. 243-258 y pp. 265-278 respectivamente. 


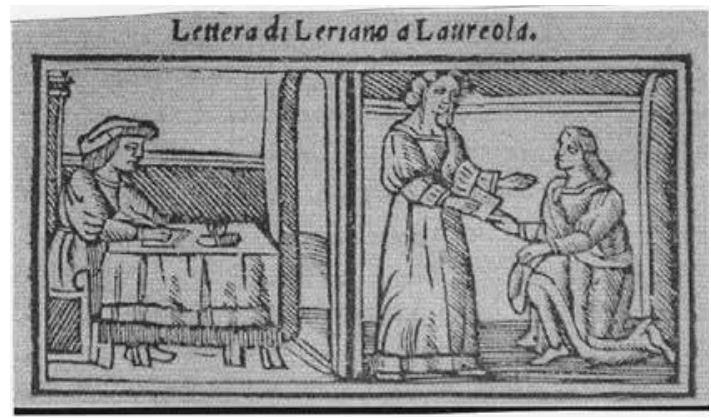

Fig. 35. Ejemplares en Barcelona, B C, Toda-I-II-9; BNE, R/3260

Pequeñas diferencias se hallan entre Zaragoza, 1523 y Venecia, 1531. En ésta se prescinde de la indicación de la portada que figura en Zaragoza, con la que Jorge Coci avisaba de la novedad: «Nuevamente historiados y bien correydo»; ahora la edición veneciana solamente anuncia: «nuevamente correydo», mientras que en el colofón precisa: «por importunación de muy muchos señores a quien la obra y estilo y lengua romance castellana muy mucho place».

La cesión, el préstamo, la compra de tacos xilográficos entre imprentas era algo habitual entre las crecientes industrias tipográficas. Podría, en efecto, considerarse que la propia edición de 1523 hubiese salido de las prensas italianas o, tal vez que Jorge Coci solicitase o intercambiase estas xilografías; algo también usual entre los talleres ${ }^{44}$.

Sorprende que la anónima Cuestión de amor, cuya primera edición conocida sale de las prensas de Diego Gumiel, en Valencia, 1513, no vaya acompañada de grabados, ya que el despliegue imaginativo se desarrolla en un escenario donde ficción literaria y realidad histórica se conforman en una «estructura centrípeta», rica en imágenes, como bien observó su editora Carla Perugini, lo que podría adornarse con estampas adecuadas a lo descrito en ciertos pasajes ${ }^{45}$. Con todo, es muy sugerente el grabado de la portada de la primera edición, ya que representa una de las escenas que en dos ocasiones se

\footnotetext{
${ }^{44}$ Precisamente, Salvá padre, cuando tuvo en sus manos la edición de Jorge Coci, Zaragoza, 1523, la consideró como trabajo sacado en alguna imprenta veneciana «por la gran semejanza de su tipo con el de la que se publicó en aquella ciudad en 1531, y por ser las láminas exactamente las mismas». (Catálogo de la Biblioteca de Salvá, II, 1670).

${ }^{45}$ Questión de Amor, Estudio crítico, edición y notas, Salamanca, Ediciones Universidad de Salamanca, Textos Recuperados X, 1995, p. 16. Sustento la observación de Rosario Consuelo González García sobre el apoyo histórico que contiene esta narración, «rompiendo - pero innovando- en sí misma el molde ficcional del género», lo que supone que «Solo quien conoce con rigor su sentido histórico, puede reconocer, en su trasvase literario, la función y sentido de la obra en que se inserta». Véase «Notas sobre la difusión y la composición de la Questión de Amor», en Nunca fue pena mayor. Estudios de Literatura Española en homenaje a Brian Dutton, ed. de Ana Menéndez Collera y Victoriano Roncero López, Cuenca, Ediciones de la Universidad de Castilla-La Mancha, 1996, pp. 305-319.
} 
evoca y describe en el relato (fig. 36). En un primer plano, un caballero embiste con la lanza a un puerco espín acosado por dos perros. Dos servidores, con sendas lanzas -y uno de ellos con cuerno de caza- completan la escena. En un plano superior, sobre corceles, departen dos parejas de caballero y dama, y dirigen su mirada al plano inferior. En el ángulo derecho superior, entre dos árboles, emerge un ciervo. La portada lleva al pie el título de la obra y una especie de sinopsis del contenido, que diestramente sugiere la escena: «Introduze se mas vna caça». En este grabado hace referencia a dos situaciones contempladas o evocadas en el curso del relato. En cierta ocasión Belisena e Isiana acuden con otros dos caballeros a una jornada de caza, «y puestos todos en sus paradas», y las dos damas acompañadas de dos caballeros, «acudió un ciervo muy grande, y dadas laxas las señoras a sus canes, los cavalleros que con ellas estavan començaron a seguirlo». La ocasión es favorable a Belisena, pues en tal momento se queda sola y surge Flamiano «impensadamente» ${ }^{46}$.

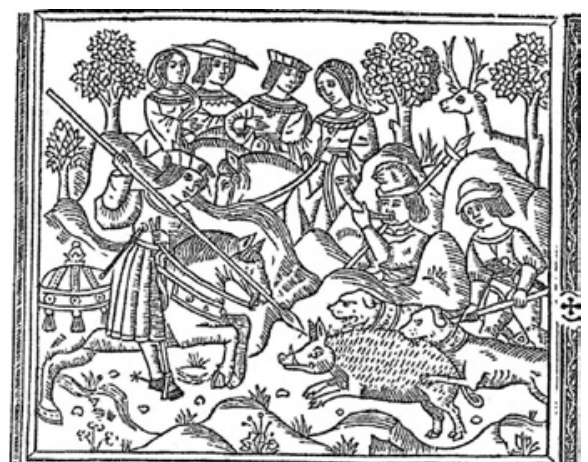

Fig. 36. Cuestión de amor

(Valencia, Diego de Gumiel, 1513), BL, C.57.

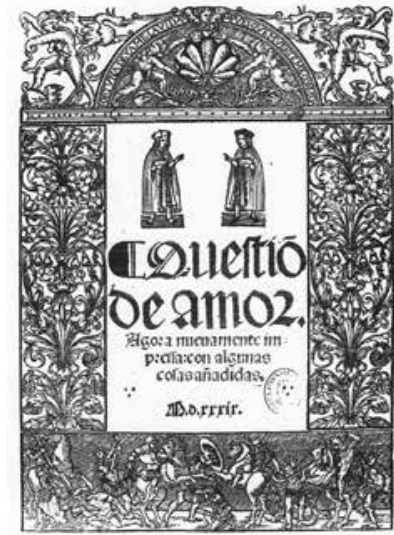

Fig. 37. Questión de amor (Zamora, Pedro Tovans, 1539), BNE, R/12644

Hay en la obra otro relato breve y emotivo de escena de caza, narrado por el propio Vasquirán a Felisel, como autor y testigo del mismo. Siguiendo una pareja de ciervos, el propio Vasquirán alcanza a matar a la hembra. La cargan en una acémila y regresan a la heredad, pero el ciervo compañero, sin temor a los cazadores y, bramando, va tras el cuerpo de su compañera. Vasquirán, conmovido y también atemorizado, manda desollar a la cierva y llenar con

\footnotetext{
${ }^{46}$ Cuestión de Amor (Valence: Diego de Gumiel, 1513), introducción, edición y notas de Françoise Vigier, Paris, Publications de la Sorbonne, 2006, pp. 196-197.
} 
heno el vacío de su cuerpo. Después ordena colgarla en un punto alto del jardín, pero al que pueda llegar el viudo ciervo compañero. El animal se queda en el propio jardín de Vasquirán y solamente saldrá «cuando constreñido por el hambre algún poco por la huerta a pacer se aparta» (pp. 209-210). Así, pues, el grabado de la portada de esta primera edición parece combinar dos situaciones que corresponden a secuencias diferentes del relato y a planos temporales distintos, alcanzando con ello a expresar plásticamente la anecdótica escena de valor simbólico para uno de los amantes de este tratado amoroso. Repárese que en la parte superior derecha del grabado asoma un ciervo.

Por el contrario, en la imprenta zamorana de Pedro Tovans, en 1539, el grabado de la portada no concuerda apenas con el contenido de la obra, salvo si se interpreta que las dos figurillas de varones dialogando representen a Vasquirán y a Flamiano. Las figuras y el marbete para el título están enmarcadas por el trabajo artístico de Juan de Vingles (fig. 37). En la base de la portada se representa una escena bélica: el enfrentamiento de guerreros a caballo. En los lados se elevan motivos vegetales. En la parte superior dos figuras femeninas y dos dragones parecen sostener un arco con la leyenda: «FORTUNA DEVAME LA VIDA PUES QUE MUERTE ME CONVIDA $»^{47}$.

Con grabados o sin ellos, el grupo de estos tratados de amor tuvo una andadura propicia hasta la segunda mitad del siglo XvI. Se difundieron en Europa en lengua francesa, italiana, polaca, inglesa y alemana; con frecuencia en versiones bilingües, como apoyo para el aprendizaje del castellano, así como en algunas libres versiones que conforman en ciertos casos interpretaciones sugestivas. La presencia de imágenes estimuló probablemente a muchos lectores, ya que impresores y libreros al constatar el interés despertado, ensancharon sus posibilidades mercantiles con el intercambio y usufructo de grabados. Sin ellos, en el grupo sentimental quedaron castigados aquellos pocos que, como apuntó Víctor Infantes, se limitaron a sobrevivir manuscritos «sin servicio lector» hasta el siglo Xx. Así, el grupo caminó en el espacio editorial dentro y fuera de las fronteras hispanas, aunque a la zaga de la prosa de ficción caballeresca, y como «género típicamente editorial, pero al amparo de una adecuada organización libresca de seguras ventas y acertada visión comercial» ${ }^{48}$.

Recibido: 21/04/2016

Aceptado: 24/06/2016

\footnotetext{
${ }^{47}$ Prescindo de otras consideraciones sobre la representación de imágenes en la Questión de amor, por cuestiones de espacio.

${ }^{48}$ Víctor Infantes, «La prosa de ficción renacentista: entre los géneros literarios y el género editorial», en Actas del X Congreso de la Asociación Internacional de Hispanistas (Barcelona 21-26 de agosto de 1989), coord. por A. Vilanova, 1992, I, pp. 467-474, cita p. 471.
} 
VESTIR LAS PALABRAS: GRABADOS XILOGRÁFICOS EN LA FICCIÓN SENTIMENTAL

RESUMEN: Análisis y comentario descriptivo sobre el discurso formal y funcional de los motivos iconográficos presentes en la ficción sentimental en su evolución y expansión a lo largo de más de media centuria del siglo XVI. Atención especial a la Cárcel de amor de Diego de San Pedro (Zaragoza, Jorge Coci, 1523) y comentario detallado del enfoque y dimensión de su función plástica. Consideración de las relaciones e interdependencia de la tradición iconográfica en el circuito editorial europeo en las obras del género sentimental.

PALABRAS ClaVE: Ficción sentimental. Imprenta. Tradición iconográfica. Grabados.

\section{Dressing Words: Woodblock Prints in Sentimental Fiction}

ABSTRACT: Analysis and descriptive comentary on the formal and functional discourse of iconographic motifs in sentimental fiction in its evolution and expansion over more than half a century of the sixteenth century. Special attention in paid to Cárcel de amor by Diego de San Pedro (Zaragoza, Jorge Coci, 1523) with detailed commentary on the approach and dimension of their artistic function. Consideration of the relations and interdependence of the iconographic tradition in the European publishing circuit of works of the sentimental genre.

KeYwORDS: Sentimental Romance. Printing. Iconographic Tradition. Woodcuts. 